\title{
PRODUKTIVITAS HIJAUAN YANG DITANAM PADA NAUNGAN POHON KELAPA SAWIT DENGAN TANAMAN CAMPURAN
}

\author{
Grass Productivity on Palm Oil Shade with Mixing Grass
}

\author{
Agung Kusuma Wijaya, Muhtarudin, Liman, Cloudia Antika, dan Dini Febriana \\ Departement of Animal Husbandry, Faculty of Agriculture, Lampung University \\ Jl. Soemantri Brojonegoro No 1, Gedong Meneng, Bandar Lampung, 35145 \\ Email: agung.kusumawijaya@fp.unila.ac.id
}

\begin{abstract}
This research intended to determine the effect of palm oil tree shade and mixed planting on grass and leguminous on productivity. This research has been done on March-June 2018 in Tanjung Agung Area, Katibung District, Kalianda, South Lampung. This research used Completely Randomized Design (CRD) with split plot design method. The treatment was implemented in this research is (1) shading, consist of two levels, which are NO (without shade) and N1 (palm oil tree shade) and (2) mixed plant species, consist of two variations; which is A1 (elephant grass and purple bush bean) and A2 (dwarf elephant grass and purple bush bean). The data which obtained were analyzed by analysis of variance on 5\% significant level, then if the result significantly difference, it were analyzed with Duncan Multiple Range Test (DMRT). The results showed that palm oil shading has not significant effect on grass productivity. there is an interaction between the type of grass and oil palm shade on the number of elephant grass and odot grass tillers. The dry matter of grass on mixed planting on land without shade was significantly different with dry matter of grass on mixed planting in palm oil shade. However, it has tendency to increase organic matter of grasss on palm oil shade.
\end{abstract}

Keywords: Palm Oil Shade, Elephant Grass, Dwarf Elephant Grass, Mixing Grass, Productivity

\section{PENDAHULUAN}

Laju pertambahan kebun kelapa sawit di Indonesia sejak tahun 2015--2017 meningkat dari 11.260.277 menjadi 12.307.677 ha, sedangkan laju pertumbuhan kebun kelapa sawit di Provinsi Lampung sejak tahun 2015--2017 juga meningkat dari 207.868 menjadi 224.175 ha (Ditjenbun, 2015). Usaha perkebunan sawit secara ekonomi memberikan devisa negara yang sangat besar dan menyediakan lapangan pekerjaan. Dilain sisi berpotensi menambah jumlah spesies fauna maupun flora yang hilang karena adanya pembukaan lahan pertanian maupun hutan secara besar-besaran. Kondisi ini berpeluang untuk Pengembangan usaha peternakan karena adanya potensi tersedianya sumber hijauan pakan ternak dibawah naungan pohon kelapa sawit. Tumbuhan di area perkebunan dianggap sebagai gulma bagi tanaman pokoknya, namun dapat dimanfaatkan sebagai pakan ternak (Purwantari et al., 2015).

Pemanfaatan areal pada lahan kelapa sawit adalah salah satu alternatif yang dapat dilakukan untuk mengatasi penyediaan hijauan pakan ternak. Jarak tanam kelapa sawit adalah 9x9 meter, ini adalah lahan potensial yang belum dimanfaatkan dan dibiarkan begitu saja, padahal secara ekonomis, disela-sela lahan perkebunan kelapa sawit dapat diusahakan budidaya hijauan pakan ternak dengan beberapa spesies tanaman yang tahan terhadap naungan (Diana et al., 2005). Tanah dibawah naungan pohon kelapa sawit mengandung kelembapan yang tinggi karena kurang terpapar sinar matahari, tanah juga mengandung kadar air yang tinggi sehingga memungkinkan hijauan pertumbuhannya cepat ditanah ini. Hijauan yang ditanam pada naungan kelapa sawit yaitu rumput odot, rumput gajah dan leguminosa siratro. Hijauan ini dipilih karena keunggulannya yaitu disukai oleh ternak ruminansia, tanaman yang mudah ditanam, bibit mudah didapat, memiliki kualitas nutrisi yang baik untuk ternak, dan mudah beradaptasi. Ketiga jenis tanaman di tanam dengan sistem pertanaman campuran dibawah naungan pohon kelapa sawit.

Tujuan dari pelaksanaan penelitian ini yaitu untuk memanfaatkan lahan dibawah naungan kelapa sawit dengan menanam hijauan pakan dan meningkatkan produktifitas hijauan rumput yang dicampur dengan leguminosa. Rumput sebagai pakan utama ternak ruminansia, sehingga perlu pengukuran produktifitas rumput yang akandibudidayakan di lahan naungan tersebut. 
Tinjauan hasil penelitian mengenai pertanaman campuran rumput dan leguminosa menunjukkan bahwa pertanaman campuran dapat meningkatkan produksi hijauan rumput yaitu menghasilkan kualitas hijauan yang lebih baik. Penggunaan pupuk anorganik seperti urea yang mengandung nitrogen $\left(\mathrm{N}_{2}\right)$ dapat dihemat dengan memanfaatkan leguminosasebagai pengikat nitrogen $\left(\mathrm{N}_{2}\right)$. Pertanaman campuran juga meningkatkan kapasitas tampung sebagai konsekuensi meningkatnya pertumbuhan hijauan (Diana et al., 2005).

\section{MATERI DAN METODE}

Penelitian ini dilaksanakan pada Januari Mei 2018 di Kecamatan Katibung, Kabupaten Lampung Selatan, Provinsi Lampung dan Laboratorium Nutrisi dan Makanan Ternak, Jurusan Peternakan, Fakultas Pertanian, Universitas Lampung.

\section{Materi}

Penelitian ini menggunakan perlakuan utama berupa naungan (N1) dan tanpa naungan (N0) dan perlakuan anak petak berupa jenis rumput yaitu rumput gajah (Pennistum purpureum), dan rumput gajah mini (Pennisetum purpureum cv. Mott). Leguminosa yang ditanam yaitu siratro (Macroptilium atropurpureum) sebagai tanaman sela pada rumput.

\section{Metode}

Penelitian ini dilaksanakan secara eksperimental dengan menggunakan Rancangan Acak Lengkap (RAL) metode spli plot design (rancangan petak terbagi).

\section{Variabel Penelitian}

Variabel penelitian yaitu penentuan produksi bahan segar rumput, penentuan produksi bahan kering rumput, penentuan kandungan bahan kering, dan penentuan kandungan bahan organik.

\section{Analisis Data}

Data yang diperoleh kemudian akan dianalisis dengan menggunkan analisis of varian (ANOVA), apabila dari analisis of varian berpengaruh nyata akan dilakukan pengujian lanjut dengan menggunakan DMRT.

\section{HASIL DAN PEMBAHASAN}

\section{Produksi segar}

Hasil analisis ragam pada penelitian ini diketahui, bahwa terdapat interaksi antara jenis rumput dan naungan kelapa sawit, hasil yang diperoleh berpengaruh nyata $(\mathrm{P}<0,05)$ terhadap produksi segar rumput gajah dan rumput odot.

Tabel 1 menunjukkan bahwa perlakuan rumput gajah tanpa naungan memberikan hasil berbeda nyata $(\mathrm{P}<0,05)$ bila dibandingkan dengan perlakuan rumput odot tanpa naungan, rumput gajah pada naungan, dan rumput odot naungan. Perlakuan rumput gajah yang ditanam tanpa naungan yaitu sebesar 166,76 ton/ ha menghasilkan produksi bahan segar rataan tertinggi dibandingkan dengan jenis rumput lainnya yang masing-masing rumput odot tanpa naungan 77,66 ton/ ha, rumput odot dinaungan sebesar 5,55 ton/ ha, dan yang terendah pada perlakuan rumput gajah tanpa naungan yaitu sebesar 1,64 ton/ha. Hal ini menunjukkan bahwa jenis rumput dan naungan mempengaruhi produksi segar hijauan. Jenis rumput mempengaruhi produksi segar hijauan, perbedaan pertumbuhan pada penanaman campuran rumput dan leguminosa disebabkan oleh faktor lingkungan, pertumbuhan dan produksi tanaman juga dipengaruhi oleh faktor genetis tanaman itu sendiri.

Tabel 1. Produksi segar pertanaman campuran

\begin{tabular}{lrr}
\hline \multirow{2}{*}{ Variabel } & \multicolumn{2}{c}{ Perlakuan } \\
\cline { 2 - 3 } & \multicolumn{3}{c}{ Tanpa Naungan } & Naungan \\
\hline -----Produksi segar (ton/ha/th)----- \\
\hline Rumput Gajah & $166,76^{\mathrm{d}}$ & $1,64^{\mathrm{a}}$ \\
Rumput Odot & $77,66^{\mathrm{c}}$ & $5,55^{\mathrm{b}}$ \\
\hline Rata-rata & 122,21 & 3,595 \\
\hline Keterangan: Nilai dengan huruf superscript yang \\
berbeda pada kolom dan baris yang \\
sama menunjukkan berbeda nyata \\
(P<0,05) uji Duncan
\end{tabular}

Perlakuan rumput gajah tanpa naungan yang jumlah produksi segarnya lebih besar dari produksi segar perlakuan lainnya hal ini di duga karena produksi rumput gajah memang lebih tinggi dari produksi rumput odot. Hal ini sesuai dengan pendapat Halim et al. (2013) yang menyatakan bahwa produksi bahan segar rumput gajah yaitu 100--200 ton/ha/tahun, sedangkan menurut Purwawangsa (2014) produksi rumput odot dapat mencapai 60 ton/ha/tahun. Produksi yang diukur hanya produksi rumput saja dikarenakan leguminosa merupakan salah satu faktor yang menentukan produktifitas rumput yang ditanam campuran. Leguminosa merupakan hijauan yang perakarannya mampu mengikat unsur nitrogen bebas yang ada di udara sehingga menurunkan penggunaan pupuk. Unsur hara tanah juga mempengaruhi produktivitas dari rumput. Setiadi (1994) menyatakan, produksi tanaman dipengaruhi oleh besarnya radiasi 
matahari, umur tanam, curah hujan, dan unsur hara tanah. Kandungan unsur hara tanah dilahan naungan lebih rendah dibandingkan dengan lahan tanpa naungan sehingga dapat menurunkan produksi segar rumput gajah dan rumput odot.

Perlakuan rumput gajah tanpa naungan yaitu rumput gajah yang ditanam di lahan tanpa naungan juga membuktikan bahwa naungan dapat mempengaruhi hijauan rumput yang tumbuh di bawahnya, cahaya yang ada dibawah naungan lebih sedikit dibandingkan dilahan tanpa naungan. Sebagian besar rumput tropis mengalami penurunan produksi sejalan dengan menurunnya intensitas sinar matahari, namun jenis rumput yang tahan terhadap naungan sering menunjukkan penurunan produksi yang relatif kecil atau bahkan masih meningkat pada naungan sedang. Hasil penelitian Farizaldi (2011) menyatakan bahwa umur kelapa sawit akan mempengaruhi intensitas cahaya dan kelembaban tanah, umur kelapa sawit yang semakin tua maka intensitas cahaya rendah dan kelembaban tanah tinggi.

Perlakuan rumput gajah pada naungan yang jumlah produksi segarnya lebih rendah merupakan jenis rumput yang kurang toleran terhadap naungan. Ludlow dan Wilson (1976) menyatakan bahwa kemampuan tanaman mempertahankan pertumbuhan pada naungan sangat bervariasi. Pertumbuhan spesies-spesies pastura sangat nyata, tergantung pada cahaya lingkungan dan biasanya kualitas energi cahaya yang tersedia sangat erat dan berhubungan positif terhadap pertumbuhan (Saravanan et al., 2008).

Penelitian dilakukan dengan sistem pertanaman campuran, rumput ditanam secara bersamaan dengan leguminosa. Bahar et al. (1998) menyatakan leguminosa bermanfaat untuk tanaman pokoknya karena mempunyai kemampuan mendapatkan senyawa nitrogen untuk hidupnya sendiri, bahkan dapat berkontribusi nitrogen untuk lingkungan maupun tanaman pokoknya, bila dapat menambat $\mathrm{N}_{2}$ udara secara efektif. Penanaman campuran antara rumput dan leguminosa akan lebih menguntungkan karena leguminosa selain mengandung gizi yang tinggi dan protein tinggi juga mempunyai kemampuan mengikat nitrogen udara bila bersimbiosis dengan bakteri rhizobium. Rumput sebagai pakan utama ternak ruminansia dapat ditanam secara tunggal, namun produksi dan kualitasnya rendah.

Produksi total leguminosa dilahan tanpa naungan yaitu sebesar 40,83 ton/ha dan produksi dilahan naungan yaitu sebesar 8,02 ton/ha produksi leguminosa menurun pada lahan naungan. Produksi legum dilahan naungan jika dibandingkan dengan produksi rumput gajah dan odot jauh lebih besar hal ini diduga bahwa leguminosa lebih tahan naungan dari pada rumput gajah dan rumput odot. Bahar et al. (1998) menyatakan leguminosa siratro atau Macroptilium atropurpureum memiliki daya adaptasi dan kemampuan untuk tumbuh bersama rumput tanpa menekan pertumbuhan rumput. Leguminosa ini juga mampu beradaptasi dilingkungan yang kurang cahaya.

\section{Produksi Bahan Kering}

Hasil analisis ragam pada penelitian ini diketahui, bahwa naungan yang berbeda berpengaruh nyata $(\mathrm{P}<0,05)$ terhadap produksi bahan kering rumput gajah dan rumput odot, namun jenis rumput yang berbeda tidak berpengaruh nyata $(\mathrm{P}>0,05)$. Tabel 2 menunjukkan produksi bahan kering tertinggi pada rumput gajah tanpa naungan. Setelah dilakukan uji lanjut Duncan hasil yang didapat menunjukkan bahwa perlakuan rumput gajah tanpa naungan yaitu 31,94 ton/ha memberikan hasil berbeda nyata $(\mathrm{P}<0,05)$ bila dibandingkan dengan perlakuan rumput gajah pada naungan yaitu 0,28 ton/ha, sedangkan perlakuan rumput odot tanpa naungan yaitu 10,80 ton/ha juga memberikan hasil berbeda nyata $(\mathrm{P}<0,05)$ bila dibandingkan dengan perlakuan rumput odot pada naungan yaitu 0,62 ton/ha. Hal ini diduga bahwa naungan pohon kelapa sawit penyebab turunnya produksi berat kering hijauan rumput. Hasil penelitian Alvarenga et al. (2003) menunjukkan bahwa tanaman yang ditanam pada kondisi tanpa naungan cenderung memiliki produksi berat kering akar yang lebih tinggi dibandingkan tanaman dengan naungan. Produksi hijauan yang toleran naungan masih dapat meningkat pada naungan sedang (Samarakoon et al., 1990).

Tabel 2. Produksi bahan kering pertanaman campuran

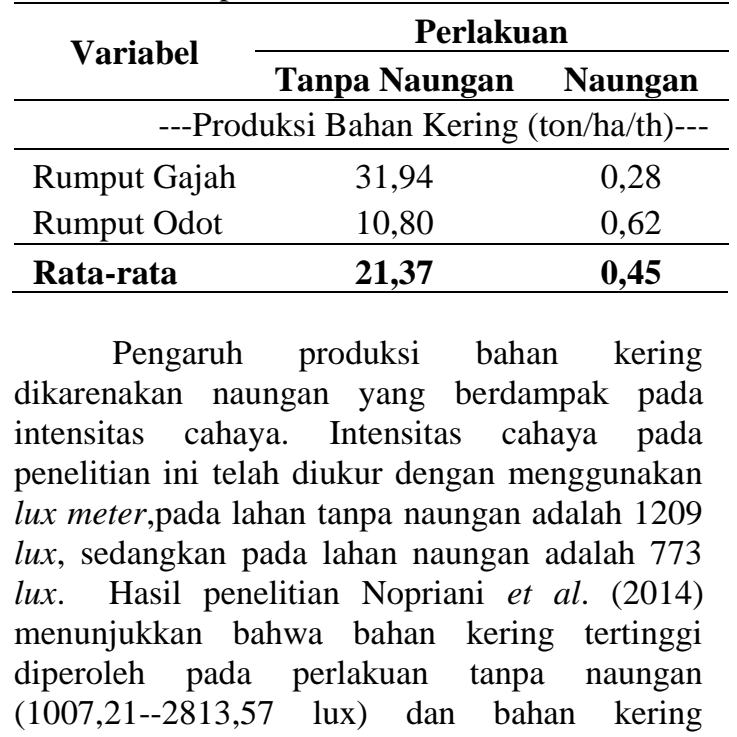


terendah diperoleh pada perlakuan naungan $70 \%$ (326,86--852,43 lux).

Bahar et al. (1998) menyatakan umur kelapa sawit kemungkinan akan mempengaruhi keragaman tumbuhan yang di bawah perkebunan kelapa sawit. Umur kelapa sawit berpengaruh karena semakin tua umur kelapa sawit maka jumlah pelepah akan semakin banyak, pelepah kelapa sawit akan semakin panjang, dan kerapatan kanopi akan semakin rapat. Hal ini menyebabkan intensitas cahaya akan semakin menurun. Fitter dan Hay (1991) juga menyatakan bahwa besarnya produksi tanaman juga di pengaruhi oleh tingkat efisiensi penggunaan cahaya yang diserap dan juga di pengaruhi oleh terganggunya keseimbangan pada sistem tanaman. Tingkat naungan yang tinggi menurunkan jumlah tunas, anakan, diameter batang, dan produksi, sedangkan jumlah daunnya meningkat sejalan dengan meningkatnya naungan. Pendapat yang sama juga didukung oleh Ludlow et al. (1974) yang menyatakan bahwa produksi bahan kering menurun dengan adanya intensitas cahaya yang rendah pada beberapa spesies rumput dan leguminosa.

Hasil rata-rata produksi kering rumput gajah pada penelitian ini di lahan N0 adalah 31,94 ton/ha sudah sangat baik, namun pada lahan naungan produksi kering nya sangat rendah yaitu 0,28 ton/ha. Halim et al. (2013) menyatakan produksi bahan kering rumput gajah yaitu 20 ton/ha/tahun. Hasil rata-rata produksi bahan kering rumput odot pada penelitian ini di lahan N0 adalah 10,80 ton/ha sudah sangat baik, namun pada lahan N1 produksi bahan kering nya sangat rendah yaitu 0,62 ton/ha. Susetyo (1969) menyatakan rumput gajah mini mempunyai produksi bahan kering 40 sampai 63 ton/ha/tahun. Hal ini dapat disimpulkan bahwa penanaman rumput lebih baik di lahan tanpa naungan agar produksi bahan kering akan lebih maksimal.

\section{Jumlah Anakan Rumput}

Hasil analisis ragam pada penelitian ini diketahui, bahwa terdapat interaksi antara jenis rumput dan naungan kelapa sawit, hasil yang diperoleh berpengaruh nyata $(\mathrm{P}<0,05)$ terhadap jumlah anakan rumput gajah dan rumput odot, setelah dilakukan uji lanjut Duncan hasil yang didapat menunjukkan bahwa perlakuan rumput gajah tanpa naungan memberikan hasil berbeda sangat nyata $(\mathrm{P}<0,05)$ jika dibandingkan dengan perlakuan rumput odot tanpa naungan, rumput gajah pada naungan, dan rumput odot naungan.

Tabel 3 menunjukkan bahwa perlakuan rumput odot tanpa naungan yaitu sebesar 22,33 tanaman/batang menghasilkan jumlah anakan rataan tertinggi dibandingkan dengan jenis rumput lainnya yang masing-masing rumput gajah tanpa naungan 9,00 tanaman/batang, diikuti rumput odot naungan sebesar 3,33 tanaman/batang, dan yang terendah pada perlakuan rumput gajah naungan yaitu sebesar 0,67 tanaman/ batang. Hal ini menunjukkan bahwa jenis rumput dan naungan mempengaruhi jumlah anakan. Jenis rumput mempengaruhi jumlah anakan hijauan, berdasarkan perbandingan jenis tanaman atau spesies rumput ini dengan jumlah anakan yang diperoleh selama pengamatan, dapat dikatakan bahwa karakter setiap spesies tanaman atau rumput memberikan respons yang berbeda pula terhadap adanya naungan. Hal ini dapat terjadi karena jumlah cahaya yang diterima oleh kedua jenis rumput ini dalam naungan mempengaruhi pertumbuhan dan produksinya.

Tabel 3. Jumlah anakan pertanaman campuran

\begin{tabular}{lcc}
\hline \multirow{2}{*}{ Variabel } & \multicolumn{2}{c}{ Perlakuan } \\
\cline { 2 - 3 } & Tanpa Naungan & Naungan \\
\hline Rumput Gajah & $9,00^{\mathrm{b}}$ & $0,67^{\mathrm{a}}$ \\
Rumput Odot & $22,33^{\mathrm{c}}$ & $3,33^{\mathrm{b}}$ \\
\hline
\end{tabular}

Keterangan: Nilai dengan huruf superscript yang berbeda pada kolom dan baris yang sama menunjukkan berbeda nyata $(\mathrm{P}<0,05)$ uji Duncan

Hasil penelitian Lukas et al. (2017) menyatakan bahwa analisis keragaman jumlah anakan $P$. purpureum $c v$. Mott pada lingkungan level naungan $0 \%$ berbeda sangat nyata lebih tinggi dibandingkan lingkungan naungan $70 \%$. Banyaknya jumlah anakan di lingkungan naungan 0\% merupakan respon tanaman terhadap sinar matahari. Pada lingkungan naungan $0 \%$, sinar matahari yang tak terbatas dimanfaatkan untuk proses fotosintesis guna menghasilkan energi berupa karbohidrat. Sudaryono (2011) menyatakan intensitas cahaya matahari berkolerasi dengan laju fotosintesis tanaman. Intensitas cahaya matahari yang rendah menyebabkan suhu udara di bawah naungan lebih rendah dan kelembapan udaranya menjadi lebih tinggi dibandingkan dengan di luar naungan. Suhu udara menentukan laju difusi zat cair di dalam tanaman, apabila suhu udara turun maka kekentalan air menjadi naik sehingga menyebabkan proses fotosintesis menurun.

Perbedaan jumlah anakan antara rumput gajah dan rumput odot yang berbeda karena memang karakteristik dari masing-masing rumput tersebut. Rumput odot menghasilkan anakan yang lebih banyak dibandingkan dengan rumput gajah hal ini dikarenakan berdasarkan 
karakteristiknya rumput odot merupakan tanaman berumpun yang dapat menghasilkan jumlah anakan banyak. Soetanto dan Subagyo (1988) menyatakan, rumput odot memiliki ciriciri seperti: merupakan tanaman berumur panjang, membentuk rumpun mirip seperti padi, tingginya dapat mencapai $1--1,8 \mathrm{~m}$. Sistem perakarannya memiliki rhizome-rhizome yang pendek, banyak menghasilkan anakan.

Perlakuan rumput gajah tanmpa naungan yang jumlah anakannya lebih rendah di duga karena rumput gajah adalah rumput yang kurang toleran terhadap naungan. faktor cahaya yang rendah pada naungan yang menyebabkan hasil fotosintesis berupa karbohidrat jumlahnya relatif sedikit dan masih dipergunakan dimanfaatkan rumput untuk pertumbuhan tinggi tanaman sehingga sampai dengan defoliasi, hasil asimilasi ini belum cukup untuk membentuk anakan. Holmes (1980) menyatakan bahwa intensitas cahaya mempengaruhi pemenuhan hasil asimilasi tumbuhan sehingga berpengaruh terhadap pembentukan anakan. Faktor cahaya akan mempengaruhi pertumbuhan daun sehingga mempengaruhi pembentukan anakan.

Proses penangkapan energi matahari dikenal dengan fotosintesis. Proses ini akan berlangsung dengan baik jika cahaya matahari yang jatuh ke permukaan tanaman melalui klorofil optimal dan akan terganggu jika sebaliknya. Cahaya matahari merupakan faktor iklim yang sangat penting dalam fotosintesis karena berperan sebagai sumber energi pembentuk bahan kering tanaman. Gangguan yang timbul dapat dilihat dari bentuk atau penampilan pertumbuhan tanaman dan pertambahan anakannya. Hal ini tentunya secara tidak langsung mempengaruhi produksi suatu hijauan makanan ternak (Sawen, 2012). Wong (1990) juga mengemukakan cahaya matahari sangat berpengaruh terhadap perbanyakan tiller (anakan) yaitu semakin tinggi intensitas penyinaran matahari semakin banyak jumlah anakannya. Hasil dari penelitian bahwa rumput odot tanpa naungan menghasilkan jumlah anakan rataan tertinggi dan yang terendah perlakuan N1A1 menyimpulkan bahwa rumput gajah dan rumput odot lebih baik ditanam di lahan tanpa naungan karena jumlah anakannya akan lebih tinggi dan maksimal dibandingkan ditanam di lahan naungan sawit karena jumlah anakannya menurun. Rumput gajah juga ternyata tidak toleran terhadap naungan dibandingkan dengan rumput odot yang lebih tahan dan toleran dengan naungan.

\section{Kandungan Bahan Kering Rumput}

Berdasarkan uji Duncan menunjukkan bahwa rata-rata bahan kering rumput pada penanaman campuran di lahan tanpa naungan sebesar $16,64 \pm 3,81 \%$ berbeda nyata $(\mathrm{P}<0,05)$ dengan bahan kering rumput pada penanaman campuran di lahan naungan yaitu $15,58 \pm 2,98 \%$

Hasil tersebut menunjukkan nilai bahan kering rumput pada penanaman campuran pada lahan tanpa naungan lebih tinggi dibandingkan dengan nilai bahan kering rumput pada penanaman campuran di bawah naungan (Tabel 4). Hal tersebut sesuai dengan hasil penelitian Alvarenga (2004) menunjukkan bahwa tanaman yang ditanam pada kondisi tanpa naungan cenderung memiliki produksi bahan kering yang lebih tinggi dibandingkan tanaman dengan naungan. Lahan naungan memiliki kandungan bahan kering yang lebih rendah. Wilson dan Wong (1982) menyatakan bahwa naungan menurunkan bahan kering green panic dan siratro.

Tabel 4. Kandungan bahan kering pertanaman campuran

\begin{tabular}{|c|c|c|}
\hline \multirow[b]{2}{*}{ Variabel } & \multicolumn{2}{|c|}{ Perlakuan } \\
\hline & $\begin{array}{c}\text { Tanpa } \\
\text { Naungan }\end{array}$ & Naungan \\
\hline \multicolumn{3}{|c|}{-- Kandungan bahan kering (\%)-- } \\
\hline Rumput Gajah & $19,33 \pm 0,23$ & $17,68 \pm 1,48$ \\
\hline Rumput Odot & $13,94 \pm 0,22$ & $13,47 \pm 0,77$ \\
\hline Rata-rata & $16,64 \pm 3,81$ & $15,58 \pm 2,98$ \\
\hline
\end{tabular}

Bahan kering terdiri atas bahan organik dan bahan anorganik, berdasarkan tabel 3 bahwa hasil rata-rata nilai bahan organik pada penanaman campuran di lahan tanpa naungan dan pada lahan naungan tidak berbeda nyata $(\mathrm{P}>0,05)$ hal tersebut menujukkan bahwa peningkatan bahan kering pada lahan tanpa naungan terletak pada peningkatan kadar bahan anorganik. Tillman et al. (1998) bahan anorganik terdiri atas lignin, mineral dengan berbagai unsur-unsurnya.

Faktor yang menyebabkan bahan anorganik pada lahan tanpa naungan lebih tinggi dibandingkan dengan lahan naungan adalah intensitas cahaya, dimana intensitas cahaya pada lahan tanpa naungan lebih besar. Berdasarkan gambar 3 dan 4, nilai intensitas cahaya pada lahan tanpa naungan sebesar 1209,3 lux dan pada lahan naungan sebesar 773 lux. Miller (1984) menyatakan Kondisi lingkungan seperti kelembaban, cahaya, dan suhu baik pada tanah dan udara akan mempengaruhi mempengaruhi proses fisiologi pada tanaman.

Tingginya intensitas cahaya pada lahan tanpa naungan memberikan pengaruh pada kadar lignin dan serat kasar hijauan. Ihsan dan Syahdar (2007) menyatakan bahwa kandungan serat kasar pada pertanaman campuran dipengaruhi oleh musim kemarau dimana intensitas cahaya dan 
temperatur lebih tinggi. Kondisi ini memungkinkan respirasi tanaman meningkat sehingga mempercepat proses penuaan sehingga tanaman cepat menimbun lignin (lignifikasi) pada dinding sel yang merupakan bagian bahan anorganik. Pada lahan naungan memiliki bahan kering lebih rendah disebabkan intensitas cahaya yang rendah. Ludlow et al. (1974) menyatakan produksi bahan kering menurun dengan adanya intensitas cahaya yang rendah pada beberapa spesies rumput dan legum. Cahaya merupakan salah satu faktor yang mempengaruhi terbuka dan tertutupnya stomata. Menurunnya intensitas cahaya akibat naungan akan mempengaruhi pembukaan stomata, sehingga aktivitas fotosintesis akan menurun. Berdasarkan hal tersebut fotosintat yang dihasilkan selama tanaman dinaungi menjadi berkurang, ini akan tercermin dari rendahnya bobot kering tanaman.

Jika dibandingkan dengan perlakuan jenis rumput, berdasarkan DMRT menunjukkan bahwa penanaman campuran rumput gajah dengan leguminosa dan rumput odot dengan leguminosa berbeda nyata $(\mathrm{P}<0,05)$ terhadap bahan kering rumput. Hal ini disebabkan karena varietas pastura memberikan respon yang berbeda pada kondisi lingkungan yang berbeda dan pertumbuhan serta produksi tanaman juga dipengaruhi oleh faktor-faktor genetis tanaman itu sendiri. Soegito et al. (1992) menyatakan bahwa setiap varietas tanaman memiliki produksi yang berbeda-beda tergantung kepada sifat genetis varietas tanaman itu sendiri.

Berdasarkan Tabel 1 terdapat nilai rata-rata bahan kering rumput gajah dan rumput odot yang ditanam campuran dengan leguminosa berturutturut sebesar $18,51 \pm 1,17 \%$ dan $13,71 \pm 0,33 \%$, keduanya memiliki hasil yang lebih tinggi dibandingkan dengan bahan kering rumput gajah menurut hasil penelitian Halim et al. (2013) sebesar $16,16 \%$ dan bahan kering rumput odot menurut hasil penelitian Sirait et al. (2014) sebesar 13,55\%. Hal tersebut menunjukkan bawah penanaman campuran dapat meningkatkan bahan kering dibandingkan dengan penanaman rumput secara tunggal.

Penanaman secara campuran dimungkinkan terjadi persaingan atau saling mempengaruhi antara komponen pertanaman yang berlangsung selama periode pertumbuhan tanaman yang mampu mempengaruhi hasil kedua atau lebih tanaman tersebut. Gardner et al. (1991) menyatakan bahwa pada pertanaman campuran leguminosa memberi sumbangan $\mathrm{N}$ pada rumput selama pertumbuhannya. Berdasarkan hal tersebut sumbangan $\mathrm{N}$ dari leguminosa yang optimum dapat menyediakan unsur $\mathrm{N}$ dalam tanah untuk menunjang pertumbuhan tanaman.
Ketersediaan nitrogen dalam tanah ini menyebabkan proses pembelahan sel akan semakin cepat terjadi. Aplikasi pupuk urea pada tanaman akan meningkatkan pertumbuhan tanaman dan sesuai dengan pendapat Bey dan Las (1991) bahwa pertumbuhan tanaman ditentukan oleh laju pembelahan dan pembesaran sel dan suplay bahan-bahan organik dan anorganik untuk sintesa protoplasma dan dinding sel yang baru.

Unsur hara yang tersedia dalam leguminosa dapat memacu pertumbuhan dan perkembangan tanaman sehingga menghasilkan bahan kering lebih besar pula. Hasil penelitian ini sesuai pendapat Salisbury dan Ross (1995) bahwa komponen utama dalam berat kering tanaman adalah senyawa polysakarida dan lignin pada dinding sel, ditambah komponen sitoplasma seperti protein, lipid, asam amino dan asam organik.

Faktor lain yaitu waktu pemanenan pada penelitian ini yaitu 57 hari pada kondisi musim hujan sehingga hijauan sudah tergolong tua. Koten (2013) mengemukakan bahwa faktor umur panen, produksi bahan kering tanaman bagian atas semakin meningkat dengan bertambahnya umur potong karena makin banyaknya waktu yang tersedia bagi tanaman untuk berfotosintesis maka makin banyak terjadi akumulasi material hasil fotosinteis didalam jaringan tanaman. Bertambahnya umur tanaman menyebabkan tanaman memasuki fase renesance dimana tanaman telah berada pada masa penuaan sehingga menyebabkan bagian tanaman mengandung selulosa dan lignin yang tinggi.

\section{Bahan Organik Rumput}

Berdasarkan analisis ragam pada Tabel 2 pada perlakuan 1 terdapat rata-rata nilai bahan organik rumput pada penanaman campuran dilahan tanpa naungan sebesar 81,79 $\pm 1,51 \%$, tidak berbeda nyata dengan nilai rata-rata bahan organik rumput penanaman campuran di lahan naungan sebesar $84,90 \pm 0,85 \%$. Meskipun pada lahan bernaungan kandungan bahan organik pada rumput tergolong baik.

Tabel 5. Kandungan bahan organik pertanaman campuran

\begin{tabular}{lcc}
\hline \multirow{2}{*}{ Variabel } & \multicolumn{2}{c}{ Perlakuan } \\
\cline { 2 - 3 } & $\begin{array}{c}\text { Tanpa } \\
\text { Naungan }\end{array}$ & Naungan \\
\hline \multicolumn{3}{c}{--Kandungan bahan organik (\%)-- } \\
\hline Rumput Gajah & $82,86 \pm 2,70$ & $85,50 \pm 4,44$ \\
Rumput Odot & $80,72 \pm 1,14$ & $84,30 \pm 1,63$ \\
\hline Rata-rata & $\mathbf{8 1 , 7 9 \pm 1 , 9 2}$ & $\mathbf{8 4 , 9 0 \pm 3 , 0 4}$ \\
\hline
\end{tabular}


Faktor nilai bahan organik pada penanaman di lahan naungan tetap baik dikarenakan intensitas cahaya rendah menyebabkan diameter daun pada hijauan lebih tinggi. Berdasarkan hasil penelitian Nopriani (2014) bahwa diameter daun pada perlakuan naungan lebih tinggi dibandingkan dengan perlakuan tanpa naungan. Diameter daun dapat memberi gambaran tentang proses dan laju fotosintesis pada suatu tanaman, yang pada akhirnya berkaitan dengan pembentukan biomassa tanaman. Peningkatan diameter daun merupakan upaya tanaman dalam mengefisiensikan penangkapan energi cahaya untuk fotosintesis secara normal pada kondisi intensitas cahaya rendah.

Intensitas cahaya sangat mempengaruhi tanaman dalam meningkatkan pembukaan luas daun dan pemanjangan tangkai daun. Selain itu, ketersediaan $\mathrm{N}$ dalam tanah sangat terbatas, ternyata ditemukan produksi biomasa tertinggi pada perlakuan naungan yang sedang dibanding pada kondisi terbuka. Pengaruh ini nyata disertai dengan konsentrasi nitrogen yang lebih banyak pada jaringan tanaman (Wong dan Wilson, 1980).

Faktor yang menyebabkan nilai bahan organik tidak berbeda nyata pada lahan tanpa naungan yaitu intensitas cahaya, penelitian berlangsung selama musim hujan sehingga intensitas cahaya lebih rendah. Intensitas cahaya yang diterima tanaman selama fotosintesis akan dimanfaatkan sebagai sumber energi sedangkan lama penyinaran mengendalikan pembungaan sebagai besar jenis tanaman. Sopandie et al. (2003) menyatakan bahwa kondisi kekurangan cahaya pada tanaman mengakibatkan terganggunya metabolisme, sehingga menyebabakan menurunnya laju fotosintesis dan sintesis karbohidrat. Bahan organik terdiri atas karbohidrat, lemak, protein dan vitamin, bahan anorganik terdiri atas mineral dengan berbagai unsur-unsurnya (Tillman et al., 1998).

Perlakuan jenis rumput bedasarkan uji anova kadar bahan organik pada penanaman campuran antara rumput gajah dengan leguminosa siratro tidak berbeda nyata $(\mathrm{P}>0,05)$ dengan penanaman campuran antara rumput odot dengan leguminosa siratro. Berdasarkan tabel 2 nilai rata-rata dari penanaman campuran antara rumput gajah dengan leguminosa siratro dan rumput odot dengan leguminosa siratro berturutturut sebesar $84,18 \pm 1,87 \%$ dan $82,51 \pm 2,53 \%$. Hasil tersebut menunjukkan kandungan bahan organik pada rumput gajah dan rumput odot memiliki nilai yang tidak jauh berbeda. Hal tersebut sesuai dengan hasil penelitian Munasik et al. (2012) dan Sirait et al. (2014) bahwa nilai kandungan bahan organik pada rumput gajah dan rumput odot berturut-turut $88,30 \%$ dan $85,55 \%$.

Berdasarkan hal tersebut kandungan bahan organik rumput gajah dan rumput odot dengan penanaman campuran leguminosa lebih rendah dibandingkan dengan kandungan bahan organik rumput pada penanaman tunggal. Hal tersebut disebabkan oleh umur panen yang dilakukan pada penelitian ini yaitu 57 hari pada musim penghujan. Jarak defoliasi pada musim penghujan sebaiknya 40 hari sekali dan musim kemarau 60 hari sekali (Soetrisno, 2008). Hal tersebut menyebabkan kandungan nutrisi menurun. Penurunan kualitas nutrisi mulai menurun pada umur pemotongan 37 hari (Norris dan Ayres, 1991). Frekuensi dan intensitas defoliasi mempengaruhi produksi dan mobilisasi $\mathrm{N}$ pada tanaman. Intensitas defoliasi meningkatkan penyerapan $\mathrm{N}$ yang dialokasikan untuk pertumbuhan daun yang diperoleh dari akar dan daun tua.

Umur panen berpengaruh terhadap nutrisi hijauan semakin tua tanaman maka akan lebih sedikit kandungan airnya dan proporsi dinding selnya lebih tinggi dibandingkan dengan isi sel. Konsentrasi nitrogen pada hijauan akan menurun pada rerumputan, ditandai dengan meningkatnya umur tanaman yang disebabkan meningkatnya bagian dinding sel dan menurunnya bagian silitol (Whitehead, 2000). Berdasarkan hal tersebut kandungan lignin pada penelitian ini tergolong tinggi sehingga menyebabkan kandungan bahan organik menjadi lebih rendah.

\section{SIMPULAN}

Hasil penelitian menunjukkan bahwa ada interaksi antara naungan kelapa sawit dan jenis rumput pada penanaman campuran dengan leguminosa terhadap jumlah anakan. produktivitas hijauan, naungan yang berbeda memberikan pengaruh nyata terhadap produksi bahan kering rumput gajah dan rumput odot, namun jenis rumput yang berbeda tidak berpengaruh nyata dan kadar bahan organik hijauan dalam naungan pohon kelapa sawit menunjukkan hasil yang lebih baik.

\section{DAFTAR PUSTAKA}

Alverenga, A.A., M.C. Evaristo, C. Erico, J. Lima dan M.M. Marcelo. 2003. Effect of different light levels on the innitial growth and photosynthetic of Croton Urucuruna. Baill in Southeastern Brazil. J Arvore. 27:53--57

Bahar, S., Chalidiah, U. Abduh, dan M Sariubang. 1998. Pertanaman Campuran Rumput dan 
leguminosa untuk Meningkatkan Produksi dan Kualitas Hijauan. Seminar Nasional Peternakan dan Veteriner. Ujung Pandang.

Diana, H.N., Roeswandy dan F. N. Hasan. 2005. Pengaruh Berbagai Level Naungan dari Beberapa Pastura Campuran Terhadap Produksi Hijauan. J AGP. 1: 67--72

Ditjenbun. 2015. Statistik Perkebunan Indonesia 2015--2017 Kelapa sawit. Direktorat Jenderal Perkebunan. Jakarta.

Farizaldi. 2011. Produktivitas Hijauan Makanan Ternak pada Lahan Perkebunan Kelapa Sawit Berbagai Kelompok Umur di PTPN 6 Kabupaten Batanghari Provinsi Jambi. JIIP. 14: 68--73.

Fitter, A. H. dan R. K. M. Hay. 1991. Fisiologi Lingkungan Tanaman. UGM. Yogyakarta.

Halim, M.R.A., S. Samsuri, I.A., Bakar. 2013. Yield and Nutritive Quality of Nine Napier Grass Varieties in Malaysia. J Anim Sci. $16: 37-44$

Holmes, W. 1980. Grazing Management $2^{\text {nd }}$ Edition. In: Grass Its Production and Utilization. Holmes, W (Ed). Lackwell Sciencetific Publication, Oxford. UK.

Ludlow, M.M. dan G.I. Wilson. 1976. Physiology of Growth and Chemical Compotition. In: Tropical Pastures Research. N.H. Show and W.W. Bryan(eds). Buletin 51. England.

Ludlow, M. M., G. I. Wilson, and M. R. Huterust. 1974. Studies on The Productivity of Tropical Pasture Plants. Shading Ongrowth, Photosyntesis and Respiration in Two grasses and Two Legumes. Aust J Agr Res. 23:415-463

Lukas, R.G., D.A. Kaligis, dan M. Najoan. 2017. Karakter Morfologi dan Kandungan Nutrien Rumput Gajah Dwarf (Pennisetum purpureum cv. mott) pada Naungan dan Pemupukan Nitrogen. $J$ LPPM Unsrat. 4:33--43

Nopriani U, PDMH Karti, dan I. Prihantoro. 2014. Produktivitas Duckweed (Lemna minor) sebagai Hijauan Pakan Alternatif Ternak pada Intensitas Cahaya yang Berbeda. JITV. 19:272-286

Purwantari, N. D., B. Tiesnamurti dan Y. Adinata. 2015. Ketersediaan Sumber Hijauan di Bawah Perkebunan Kelapa Sawit untuk Penggembalaan Sapi. Wartazoa. 25:047054

Purwawangsa, Hadian dan W.P. Bramada. 2014. Pemanfaatan Lahan Tidur untuk Penggemukkan Sapi. J. Ris. Keb. Pert. Ling. . 1: 92-96

Samarakoon, S.P., J.R. Wilson dan H.M. Shelton. 1990. Growth Morphology, and Nutritivevalue of Shaded Stenotaphrum secundatum, Axonopus compressus and Pennisetum clandestinum. J Agr. Sci. 114:161--169

Saravanan, R., K.Sunil, N.A. Gajbhiye dan S. Maiti. 2008. Influence of Light Intensity on Gas Exchange, Herbage Yield an Andrographolide Content in Andrographis paniculata (Nees). J Hort Indian. 65: $220-225$

Sawen, D. 2012. Pertumbuhan Rumput Gajah (Pennisetum perpureum dan Benggala (Panecum maximum) Akibat Perbedaan Intensitas Cahaya. JITT. 2: 17-20

Soetanto, H dan I. Subagyo. 1988. Landasan Agrostologi. Universitas Brawijaya. Malang.

Setiadi. 1994. Kentang Varietas dan Pembudidayaan. Penebar Swadaya. Jakarta

Steel, R.G.D dan J.H. Torrie. 1995. Prinsip dan Prosedur Statistika. Gramedia Pustaka. Jakarta.

Sudaryono. 2011. Pengaruh Bahan Pengkondisi Tanah Terhadap Iklim Mikro pada Lahan Berpasir. JTL. 2:175-184

Susetyo. 1969. Hijauan Makanan Ternak. Direktorat Peternakan Rakyat. Dirjen Peternakan, Deptan. Jakarta.

Wong, C.C., 1990. Shade Tolerance of Tropical Forages: a review. In: ACIAR Proceding Forage for Plantation Crop. Shelton, H.M. and W.W.Stur (Ed). 32:64 